\title{
SPANISH LANGUAGE ACQUISITION IN TERTIARY EDUCATION: THE ACTUAL SITUATION IN LATVIA
}

\author{
Agata Babina ${ }^{1}$
}

\begin{abstract}
The data published by The Instituto Cervantes (2021) prove that Spanish language use in the world is constantly rising. The current number of native speakers is 489 million people, and there are more than 22 million learners worldwide. It is the fourth most spoken language in the EU and the third in the UN. The newest Latvian Educational Standard states that the first and second-level educational institutions should offer a minimum of two foreign language acquisition. Nevertheless, the Latvian Educational Curriculum does not include Spanish as an option; therefore, it lacks institutional support to establish Spanish studies in all educational levels with the proper follow-up. The article presents the current situation in various study programs proposed by several Latvian tertiary education institutions in 2020/2021. The data has been collected by contacting current Spanish lecturers and analyzing the current study programs offering Spanish language acquisition in tertiary education institutions mentioned in the article. The analysis presents the content of the study programs in the bachelor and master study levels and the estimated number of students in each study program. It is a panoramic insight into Latvia's Spanish language teaching situation, which is necessary to understand Latvian-speaking Spanish learners' needs, existing resources for Spanish language teaching, and a further perspective for promoting Spanish studies in Latvia. It proves a lack of institutional cooperation to provide the constant Spanish language acquisition from the first till the tertiary educational level that would improve the general recognition of Spanish and its need in Latvian society as a part of the European Union.
\end{abstract}

UDC Classification: 811.134.2, DOI: https://doi.org/10.12955/pss.v2.198

Keywords: Spanish acquisition, tertiary education in Latvia, Educational Curriculum

\section{Introduction}

The data published by The Instituto Cervantes about the Spanish language situation in the world show the current number of 489 million native speakers and more than 22 million learners in 110 countries worldwide (Fernández; 2020, p. 33). It is the second most spoken native language globally, second most spoken foreign language (Fernández; 2020, p. 21), and the fourth most learned foreign language in the European Union (EU). It is also the first one mentioned by those who would like to learn a new language (Flash Eurobarometer; 2018, pp. 15-16). The number of Spanish users in 2020 reaches $7.5 \%$ of the world population (Fernández; 2020, p. 18). In the European Union as a whole, the Spanish language is judged to be the fourth most useful language, following English, German and French, but in Latvia, the interest in Spanish is much lower. Logically, considering Latvia's geopolitical situation and the number of people whose native language is Russian (37.2\% of the population), the Russian language is at the forefront of foreign languages and holds second place behind English (LVA; 2016, p. 48).

In contrast, German retains third place in foreign language learning, but its popularity is declining. The most recent study on foreign language learning in Latvia was published in $2016^{2}$. It shows that only $1 \%$ of the population in Latvia understands Spanish, while in the European Union, 7\% of the population knows it. It was also found in 2012 that $14 \%$ of the population of the European Union considered Spanish as useful for personal development, while in Latvia, it was only $2 \%$ of the population (LVA; 2016, p. 67). According to the Eurobarometer study in 2018, $35 \%$ of Europeans already mention that Spanish would be the most valuable foreign language to learn in the future (Flash Eurobarometer; 2018, 16).

Nevertheless, the interest in Spanish in Latvia is much lower than in other countries, despite the growing popularity of this language globally. It is also true that very little has been done by now to promote the use of the Spanish language and its study possibilities. In 2021 Latvia celebrates 100 years of LatvianSpanish diplomatic relations, but there is still a lack of overview of this cooperation's actual achievements, benefits, and perspectives. Spanish language and culture are still seen as distant and stereotypical. Students undertaking Spanish language and culture studies know little or almost nothing about Spain because secondary education does not focus on European studies, multilingualism, and intercultural relations promoted through the European Commission's program Erasmus + and Common European Framework for Languages. A deeper insight into the actual Spanish study possibilities offered by the Latvian Educational System is needed to raise the discussion about the content of what could be called European education, not only on the local but also international level. Therefore the research aims

\footnotetext{
${ }^{1}$ Liepāja University, Faculty of Humanitarian and Art Sciences, Liepāja, Latvia, agata.babina@liepu.lv

${ }^{2}$ Currently the new research is being carried out but the results will be available later in 2021
} 
to analyze the current situation of Spanish language in Latvian tertiary education institutions and discover why it is still so poorly known and used by Latvians.

\section{Methodology}

The present research is introduced by a diachronic and descriptive analysis of the Spanish language acquisition in Latvia since the beginning of the 20th century. It analyses the data encountered in the Latvian newspaper archive (periodika.lv), encyclopedic edition about linguistics in Latvia (Bankavs \& Jansone; 2010), and relevant publications of Spanish professors (prof.) Māra Rozenberga (2014) and Ana León Manzanero (2017). Furthermore, the information is compiled with the newest data about the current situation in Spanish language study and research in Latvian tertiary education by personal correspondence with current lecturers in Latvian universities and colleges: Alla Placinska (University of Latvia), Alberto Torres (University of Latvia), Ana León (Latvian Academy of Culture), Rafael Martín (Ventspils University College).

\section{The language situation in the EU and Latvia}

As stated in Eurydice Report 2017 about Foreign Language Acquisition in European Schools, the Barcelona objective (2002) not only suggests learning of a foreign language but also indicates the minimum number of two foreign languages all European pupils should learn in addition to their first language (Eurydice; 2018, p. 7).

Almost all pupils in Europe learn English as a second language, and in almost half of the education systems, it is a compulsory subject. Those who learn two foreign languages usually choose another language of the world, such as French, German, Spanish, Italian, or Russian. The same applies to countries where a wider range of languages is offered (Eurydice 2018, p. 20).

According to the latest Latvian educational curriculum (Curriculum), which entered into force on 1 September 2020, the second foreign language in general education schools is expected to be taught from the 4th grade, so at the age of 10 . At the secondary school stage, all pupils should learn one of the languages of the European Union (English, German or French) at least to the level B2 (Optimal level) and, in the second foreign language (English, German, French or Russian), at least till the level B1 (General level).

The number of hours to meet the minimum requirements for two foreign languages is set together to apply the number of hours to its pupils' language skills and context. All four foreign languages can also be studied at the following optimal and higher levels. The school can also offer secondary school students a third foreign language as the specialized free-choice course "Third foreign language". Depending on the number of hours offered, pupils can reach A2/B1 (General level) (Skola 2030).

The curriculum provides secondary school pupils who have reached language level B2 and an interest in foreign languages a choice of an in-depth foreign language course called "Foreign language II" that includes literary and academic language studies and research projects in a foreign language. With the in-depth course, the results to be achieved at the highest level in one of the four foreign languages (English, German, French or Russian) reach C1. During the course, pupils are supposed to read, analyze, translate and develop literary and academic texts to allow the targeted and skilled communication of all learned languages in the national and international environment, to prepare for foreign education and the use of foreign languages in the future professional activities (Skola 2030).

The results of this newly developed curriculum will be evaluated in a few years' time when existing pupils will have passed through it. Unfortunately, Spanish is not considered one of the foreign languages taught in Latvian education despite its demand on the international level. Language learning is going indepth, but language diversity is still quite limited. For the languages included in the curriculum, the Ministry of Education and Science shall approve the relevant teaching literature (ALEPH). This means contrastive research about Latvian and Spanish languages and contribution to this linguistic aspect will still be very rare. Therefore it is crucial to boost this topic academically by providing good quality tertiary education proving that Spanish is a rich and very needed language on a European level. The further research provides an insight into the current studies of Spanish language and culture provided by several institutions of Latvian tertiary education. 


\section{Development of Spanish language studies in Latvian tertiary level education}

With the foundation of the University of Latvia (LU) in 1919 and thanks to the historian and Romanist Arnold Spekke, Latvian students can learn the history of Spanish literature and the historical grammar of Spanish. Arnold Spekke had mastered Roman languages at the Faculty of Philology, Emperors' University of Moscow (Russian Empire) (Stradins; 2007). During the Republic of Latvia and the USSR, Latvian teachers gained education in Russian universities, mostly in Saint Petersburg (Leningrad) and Moscow. With the loss of independence of Latvia (1940), the possibility of studying Spanish is also disappeared until 1978.

Professor Māra Rozenberga has provided an immense contribution to the development of Spanish language acquisition in Latvia. In 1995 the author issued the first Spanish textbook, Spanish for beginners. Over the next two years, the author issued a Spanish textbook in two parts, re-issued in 2002. Over the years, the content of the book has not changed, but from two parts, it has been combined into one. This edition was also released in 2008 and 2012 (Rozenberga; 2014).

The time when the first textbook drawn up by M. Rozenberga is being issued coincides with the establishment of Spanish language study programs in two tertiary education institutions in Latvia, the University of Latvia (LU) and the Latvian Academy of Culture (LKA) (Leon; 2017, p. 272).

Spanish's methodology and teaching style as a foreign language have also changed significantly over the last decade. Until then, the Spanish lecturers had obtained Spanish philology education at Russian universities (Moscow and Leningrad (current Saint Petersburg)) during the Soviet Union. Accordingly, language learning was based on a grammatical translation method, emphasizing the mother tongue, not on the cultural aspect and the acquisition of the substance in the target language. The textbooks drew by the professor also confirm this. M. Rozenberga mentioned above. A serious milestone took place in 2005/2006, when the lecturers financed by Spanish government scholarship program MAEC-AECID ${ }^{3}$ had first arrived in Latvia, with an appropriate qualification in Spanish linguistics (ELE) ${ }^{4}$. For the first five years, universities also received financial support to purchase specialized manuals issued in Spain. The student finally came to the center and learning was based on the communicative approach, thus educating professionals with good language and cultural knowledge at local level (León; 2017, pp. 278279).

Nevertheless, the demand for foreign language knowledge on European and national levels rises, it doesn't spread the diversity of languages to be acquired. The newest Latvian Educational programs still keep the traditional frame of English, Russian, German, and French as traditionally taught languages in Latvian schools and, therefore, the demand in tertiary education. As National Centre for Education does not provide any methodical recommendations for the acquisition of the Spanish language in the State educational establishments, Spanish teachers and lecturers in Latvia are responsible for raising their qualifications, learning content planning, and choosing the appropriate materials, which, on the one hand, enables the freedom to vary with the content of the training, but on the other hand, leads to much greater responsibility for it (Maslo; 2003, p. 130). According to a long-standing study of a guest lecturer of LKA Ana León Manzanero (2017, pp. 278-279), Spanish lecturers in Latvia choose teaching materials issued in Spain, the content of which complies with the Common European Framework of Reference for Languages (CEFR). However, they are not available in any of the Latvian bookshops. They are ordered online from the Spanish publishing houses. This complicates the rapid access to the manuals and prevents students from buying them because the purchase and delivery is very expensive for an average Latvian student.

One of the advantages of the Spanish language lecturers in Latvia is that students have grown and lived in a country with several languages, and many speak at least two foreign languages. On the other hand, since the primary school years, the first foreign language has been included in the curriculum, which students learn before university (in almost all cases English, although some have studied French, German or Russian). A large number of students with skills and experience starting Spanish language studies undoubtedly facilitate the acquisition of a new language (León; 2017, p. 284). Thus, the Spanish

\footnotetext{
${ }^{3}$ MAEC-AECID scholarship programme is financed by Spanish Ministry of Foreign Affairs and Cooperation and Spanish Agency of International Cooperation (Ministerio de Asuntos Exteriores y Cooperación - Agencia Española de Cooperación Internacional).

${ }^{4}$ ELE - Español lengua extranjera (Spanish Foreign Language)
} 
language learning, as in the case of other less popular foreign languages, is most common for the Latvian speaker, the third language, and he/she already has learning experience, knowledge of learning to learn foreign languages, and general competencies in contrastive studies.

\section{Spanish studies at the University of Latvia}

In 1995, a Romance Language Department unifying French, Italian and Spanish lecturers was created at the University of Latvia (LU). Since 2000, it has been led by prof. Alla Placinska had acquired her Master's degree in Spanish and Portuguese language at Moscow University in 1986 and Ph.D. in Philology in LU in 2001 (Bankavs \& Jansone; 2010). Since 2012 Spanish language studies have been realized under the custody of the Iberian and Latin American Study Centre, led by prof. Alla Placinska. Since the same year, as part of the LU International Scientific Conference, the Centre starts organizing a separate section of the conference dedicated to Spanish language and culture studies, which takes place every year.

Every third year, the LU International Symposium Language for International Communication is organized where Spanish is one of the working languages. The symposium of 2019 included already 25 presentations in Spanish by participants even from Paraguay (A. Placinska; personal communication, 6 March, 2021).

By 2020, LU offered several Bachelor's study programmes, which also integrated Spanish language studies: French Philology, English Philology, German Philology, and Modern Languages and Business Studies. French Philology provides an opportunity to learn in one of the three two-language modules: French-Italian, French-Spanish, and French-German. The program has a cross-disciplinary character, providing academic education in Romance and/or Germanic studies, including professional guidance in culture studies and language teaching and translation. The program aims to prepare competent and competitive French and Italian/Spanish/German language specialists for public and private bodies that are relevant to the Bachelor's level, who understand the environment of Romance and Germanic areas and are able to make integrated use of the language, cultural knowledge and skills acquired, as well as practical skills in translation and language didactics (LUBSP). The language and cultural subjects to be studied in this program correspond to 32 credits $^{5}$ (48 ECTS) and 12 (18 ECTS) credits, whereas in other programs (see below) 24 credits (36 ECTS).

The LU study program, English Philology, offers two sub-programs: English studies and EnglishScandinavian studies. The study program offers in-depth knowledge of linguistics (including phonetics and phonology, morphology, syntax, semantics, and terminology), literature (including knowledge of British and American literature in cultural and historical contexts), and cultural studies (mainly in relation to Great Britain, United States, and Canada), and the second foreign language is learned at a high level (i.e., Spanish, French, German, Italian or Russian) (LUBSP).

In the German Philology program, students have the opportunity to learn a second foreign language, including Spanish. The study program consists of two modules specializing in linguistics, translation, culture, and literature. The Spanish language is taught in the study course "Contrastive Studies" (LUBSP).

The four-year-long Bachelor's study program Modern Languages and Business Studies offers academic knowledge in applied linguistics and commercial sciences. It develops intercultural communication skills, entrepreneurial skills, skills to work on a team, initiative, and interest in working on the international labor market. The study program allows one to choose one of the language modules: English-French, English-Spanish or English-German, in which students acquire knowledge and skills in the applied English and second foreign language. Students from the second year of study have the opportunity to learn a third foreign language. In the case of the choice of the English-Spanish module, students learn cultural studies, applied Spanish, translation basics, Spanish geography and history, and the Spanish history of literature and art (LU MLBS).

All together with free-choice (Part C -2 credits (3 ECTS)) courses at the Spanish bachelor level, a total of around 200 students per year are enrolled in the LU Faculty of Humanities (A. Placinska, personal communication, 5 June, 2020).

\footnotetext{
${ }^{5}$ According to Latvian Educational system 1 credit corresponds to 1,5 European Credit Transfer and Accumulation System ECTS (AIC)
} 
LU is the only institution of higher education in the Baltic States, offering masters' degree in Romance Studies with a Spanish, French or Italian in the program Romance Studies since 2011 (Leon; 2017, 276). In order to begin studies in this program, a student must certify Spanish knowledge at the level of learning of B2 either with a bachelor's degree in the above-mentioned Bachelor's level study programs LU, LKA, or with examination certificate DELE (Diploma de Español Lengua Extranjera). By 2020, it is also provided by the European language and cultural studies of the LiepU study program in English and Spanish.

By 2021, LU has prepared new bachelor's and master's programs for licensing. Study program Anglistics, European Languages and Business studies with three sub-programs: English, EnglishScandinavian and European Languages and Business Studies (LUELB), study program Philology with sub-programs: French Philology, Classical Philology, Russian Philology, Finno-Ugric Studies, German Philology, where, like so far, a higher proportion of Spanish courses is in French Philology program, but a separate direction in Spanish is not foreseen (LUF).

\section{Spanish studies at Latvian Academy of Culture}

The Latvian-Spanish Intercultural Relations bachelor program in the Latvian Academy of Culture (LKA) was developed by Prof. Alla Placinska in 1996-2011. Since the beginning, this program has been joined by native-speaking lecturers from Spain, some of whom have remained in Latvia and continue their work as Spanish lecturers in LKA and LU. Among them are certainly Alberto Torres Fernández, Ana León Manzanero, and Miguel Pérez Sánchez, who have linked their lives to academic work in Latvia. Alberto Torres graduated in theatre criticism studies at the University of Leningrad in 1989. He was LKA lecturer until 2011, and since then, he has been working in LU.

In 2004, the DELE Centre was established by LKA. Ten years later, the function of such a center is also assigned to the LU Iberian and Latin American Study Centre. The two in Latvia are coordinated by representing the Instituto Cervantes in Warsaw. Unfortunately, none of the Baltic States has the representation of this institution established in 88 cities worldwide (Instituto Cervantes). The Instituto Cervantes' coordinated centers shall organize centralized examinations for Spanish learners once or twice a year, enabling an international diploma to be obtained at a certain level of learning (A1 to C2).

Since 2015, Ana León Manzanero is organizing the annual International Conference of the Academy of Culture Jornadas de ELE en Riga that gathers the Spanish language teachers of the Baltic Sea Region, sharing their teaching practices, presenting their teaching methods and tools. These workshops are attended by both private language centers, primary schools, secondary schools, and teachers from the Instituto Cervantes from Baltic Sea Region. She also works as a researcher for the international research project, the Spanish language in Europe (El español en Europa), led by the University of Heidelberg in Germany and the University of Zurich in Switzerland (LKA; 8 March, 2021; Manzanero 2017).

LKA bachelor study program Latvian-Spanish Intercultural Relations currently accounts $25 \%$ of the total content of studies for the acquisition of Spanish. Students are admitted to this programme every four years. Students learn the language intensively for the first two years: in an integrated course, students study communicative grammar, functional lexicology, and aspects of Spanish culture. Already in the second semester, students are studying Geography of Spain, in the third - Spanish history, which proves language acquired and the capacity to use language in deeper discussions. Special attention is paid to acquiring professional skills in such courses as "Applied Spanish", "Oral and Written Translation", "Latvian-Spanish Cultural Relations in the European Context" or "Project Management in an Intercultural Context" under the leadership of the Spanish guest lecturer. At the end of the studies, students of this program acquire $\mathrm{C} 1$ level language proficiency, demonstrating the high quality and intensity of their studies. In addition, a great deal of attention is also being paid to the acquisition of subjects such as Spanish geography, history, and literature, as well as to the higher courses of language stylistics, translation, Latvian-Spanish relations. Overall, the study program offers Spanish learning of 83 credits (124,5 ECTS). At the same time, other LKA students have the opportunity to learn Spanish as a foreign language of choice at the A1-A2 level (A. León; personal communication, 26 June, 2020 and 8 March, 2021).

LKA students have the opportunity to participate in the mobility of ERASMUS programme and to study choosing one of the following Spanish universities: Universidad de Alcalá, Universidad de Valladolid, 
Universidad de Valencia, Universidad de Nebrija, Universidad de León or Universidad de Cáceres (Prakselv).

LKA works with the Spanish Embassy and several Latin American Honorary Consulates (Colombia, Chile, Mexico, Brazil, Ecuador) in Latvia. With the support of the Spanish Embassy, students from the academy participate in several cultural events each year. Students perform both organizational and creative work by setting up theatrical performances, performing Spanish or Latin American songs and dances (LKA). A Spanish cultural week has been organized for several years, whose resonance has unfortunately not yet been reached outside the capital of Latvia.

\section{Spanish studies at Liepaja University}

In Liepaja University (LiepU) Bachelor's study program European Language and Culture Studies since 2016 provide the opportunity to undertake Spanish-English modules besides English-Russian, EnglishGerman, English-French modules existing already previously. Students learn Spanish as a second foreign language in grammar, orthography, phonetics, communication, and text analysis from the first semester. In the following years, they follow courses in "Spanish lexicostylistics", "Translation practice", "Spanish and Latin American Culture Studies" and "Spanish Literature of the 20th Century". In total, during the 4-year studies, students obtain 67 credits (100,5 ECTS) in various Spanish language and culture courses and 41 credits (61,5 ECTS) in the 3-year program (EVKS 2016). At the end of their studies, students acquire Spanish-language knowledge corresponding to the level of B2 language proficiency. ${ }^{6}$

LiepU students have been enrolled in international projects, such as translating subtitles for Mexican movies presented in cinemas in Riga and Liepaja (2018 and 2019). In the semester of 2019/2020, LiepU students, in cooperation with the Chechen State Pedagogical University (Russian Federation), have been working on an online Chechen-Russian-Latvian-Spanish conversational dictionary ${ }^{7}$ involving students from Baltic and European Languages and Cultural studies. Spanish students have so far travelled in Erasmus mobilities to Universidad de Córdoba and Universidad de Valencia.

In Liepaja, 2019./2020 was the first year of studies. When the Spanish module had all study years in the Spanish module, the total number of Spanish students (excluding part C course) was 19, including Erasmus mobility students and full-time international students studying European languages and cultures. The amount might seem insignificant, but this provides the possibility of individual supervision for each student and intense learning with high achievements in language acquisition and elaboration of their individual research.

Spanish language as a free choice course (part C) is also offered in other study programs (Business and Organisation Management, Culture Management, Tourism and Recreation Management) by selecting it as a free course with 2 credits (3 ECTS).

\section{Spanish studies in other tertiary educational institutions in Latvia}

In Ventspils University College (VeA), Spanish has been provided as a third foreign language since 2012. Currently, the Spanish language, starting in the second year of study, is acquired by the students in the study programme Translation, English, and German translation modules. In Spanish, the following specialization courses are offered for four semesters: "Basic Spanish I", "Basic Spanish II", "Applied Spanish I" and "Applied Spanish II". Since 2016, more emphasis has been placed on translation aspects, which means that students learn the basic vocabulary and grammar at the beginning of their studies, and the translation process is often carried out through English, focusing on the translation of terms, names and cultural concepts. Unfortunately, this has lowered the overall level of Spanish studies in VeA corresponding mostly to A2 level of language proficiency. The average number of Spanish students at Ventspils University is 45 students per year (2017/2018 academic year 59 students and 2019/2020 academic year - 41 students) (R. Martín; personal communication, 13 June, 2020).

Spanish as a free-choice course with 2-6 credits (3-9 ECTS) can also be acquired at Daugavpils University (DU), Riga Technical University (RTU), RISEBA University of Applied Sciences (RISEBA), School of Economics and Culture (second foreign language in the Translation study program), (ESA), Riga Graduate School of Law (RGSL) (A. Placinska; personal communication, 6

\footnotetext{
${ }^{6}$ First graduation in the Spanish module took place in June 2020.

${ }^{7}$ Available on https://vardnica.liepu.lv/?s=v\&lang=lv
} 
March, 2021; A. Torres, personal communication, 10 March, 2021). The amount of lectures provided in these institutions is insignificant compared to the previously mentioned.

The overview provided in the present article has been possible thanks to the communication with the colleagues working in the mentioned institutions, who are the true testimonies of the process, meanwhile, the universities try to change and adapt the study programs after each accreditation period, and the previous information has been erased from the offer.

\section{Conclusions}

The Educational system is strongly influenced by countries' geopolitical situations and history, The most known Spanish language professors in Latvia have acquired their education in Russian universities that is interesting to mention in nowadays European context. Despite the fact that Spanish teaching in Latvia started nearly a hundred years ago, its status in both, secondary and higher educational institutions is still fragile, particularly as the Latvian education system does not consolidate nor supports Spanish language teachers at the national level, nor does it promote the availability of appropriate quality manuals in the Latvian market Instead the Educational Curriculum still gives preference to traditionally taught foreign languages: English, German, French and Russian. Latvia, a European country, still lacks of quality researches and in-depth studies in such a big language as Spanish, and its value is not appreciated on a national level. Moreover, there is no institutional support system, such as an association of Spanish teachers, giving any guidelines for their work in Latvia. The creation of a non-governmental entity could bring stronger influence on policymakers.

Spanish learning, compared with, for example, the acquisition of French, is still little common and rarely presented as a second or third foreign language in Latvian educational institutions, except for private language centres that have so far contributed much more to the popularity of this language than public schools and universities.

Although the Spanish language is currently available in several Latvian universities, the abovementioned LU and LKA are clearly distinguished, not only in the 1990s, but also since 2005 almost every year (except in the 2012/2013 academic year) with the Ministry of Foreign Affairs and Cooperation of Spain the support of the Spanish-language lecturers, which have received a state-paid grant (MAEC-AECID program) for 12 months of work abroad, in this case, in Latvia. It certainly promotes the quality of studies and the possibility for students to learn Spanish, not only under the guidance of the mother tongue user but also in the case of qualified Spanish speakers as foreign languages (ELE).

On the one hand, there is a small number of students in regional higher education institutions, but on the other hand, it provides the possibility for the lecturer to get closer to students, devote individual time and work effectively with high language learning results, which in the case of Liepaja reaches level A2 at the end of the first year of study.

From another perspective, it outlines a broad working field for the development of the relevant field in the context of language learning in Latvia, which states that it is apparently necessary to start based on what and how to teach Spanish for Latvian speaking students.

Taking the constantly rising Spanish speaking population and the European politics on multilingualism, into consideration in the long term, there might be a shortage of Spanish speakers in Latvia who could work with Latvian-Spanish, Spanish-Latvian studies or be Spanish speaking teachers and lecturers in order to promote the learning of Spanish in schools and universities.

It would be of great value to do comparative research about Spanish language studies in all three Baltic States sharing the common historical background and seek the possibilities to develop a cross-border study programs to attract more students and make an influence on decision-makers.

\section{References}

AIC (2021, April, 23). Akadēmiskās informācijas centrs [Academic information Centre] Eiropas Kredītu pārneses sistēmas, ECTS [Credit point system, ECTS]. http://www.aic.lv/portal/izglitiba-latvija/kreditpunktu-sistema

ALEPH. Izglītīibas un zinātnes ministrija. IZM apstiprinātā mācību literatūra vispārējās izglìtības programmu apguvei [Manuals approved by Ministry of Education and Science.] Retrieved from https://kopkatalogs.lv/F/?\&func=find-b0\&local_base=isc01

Bankavs, A. \& Jansone, I (2010). Valodniecība Latvijā: fakti un biogrāfijas: enciklopēdija. [Linguistics in Latvia: facts and biographies.] Rīga: LU apgāds, 2020, 37-206. 
EKA (2021 March, 7). Ekonomikas un Kultūras Augstskola [EKA University of Applied Sciences]. Tulkošana [Translation] Retrieved from https://www.augstskola.lv

Eurydice (2018). Eurydice īsais apskats. Pamatdati par svešvalodu mācīšanu Eiropas skolās, 2017. EACEA. N. Baïdak, M.P. Balkon \& A.Motiejunaite. 7-20.

EVKS (2016). Liepājas Universitāte Humanitāro un mākslas zinātṇu fakultāte. Tipveida plāns: Studiju programma Eiropas valodu un kultūras studijas (franču/krievu/latviešu/spānu/ vācu valodās) [European Language and Culture Studies (French, Russian, Latvian, Spanish, German) Study Standard] 2016 March, 31.

Fernández Vítores, D. (2020). El español una lengua viva. Informe 2020. El español en el mundo. Anuario de Instituto Cervantes. Madrid: Instituto Cervantes: 2020, 18-19.

Flash Eurobarometer (2018). The European Educational Area. Survey requested by the European Commission, DirectorateGeneral for Education, Youth, Sport and Culture and coordinated by the Directorate-General for Communication: 2018, 1-16 Instituto Cervantes. La institución. Retrieved from https://www.cervantes.es/sobre_instituto_cervantes/informacion.htm León Manzanero, A. (2017). Enseñar español en letonia. M. C. Méndez Santos y M. M. Galindo Merino (Eds.) Atlas del ELE. Geolingüística de la enseñanza del español en el mundo. Volumen I. Europa oriental. Madrid: EnClaveELE, 271-287.

LKA (2021 March, 8). Latvijas Kultūras Akadēmija. Ana Manzanero León. Docente. [Docent.] Retrieved from https://lka.edu.lv/lv/par-akademiju/docetaji/ana-leon-manzanero/

LKA (2020 June, 16). Latvijas Kultūras akadēmija. Starpkultūru sakari Latvija-Spānija [Intercultural relations Latvia-Spain.] Retrieved from https://www.prakse.lv/study/17445/latvijas-kulturas-akademija/starpkulturu-sakari-latvija-spanija

LKA (2021 March, 7). Latvijas Kultūras akadēmija. Starpkultūru sakari [Intercultural relations]. Studiju saturs [Study content]. Retrieved from https://ka.edu.lv/lv/gribu-studet-akademija/studijas/bak1/starpkulturu-sakari/

LUBSP (2021 June, 20). Latvijas Universitāte. Bakalaura studiju programma [Bachelor Study programmes]. Retrieved from https://www.lu.lv/studijas/fakultates/humanitaro-zinatnu-fakultate/bakalaura-limena-studijas/

LUEVB (2021, March, 7) Latvijas Universitāte. Eiropas valodas un bizness. [Latvia University European Languages and Business.] Retrieved from: https://www.lu.lv/studijas/fakultates/humanitaro-zinatnu-fakultate/bakalaura-limenastudijas/anglistika-eiropas-valodu-un-biznesa-studijas/

LUF (2021 March, 7) Latvijas Universitāte. Filologija. [Philology.] Retrieved from: https://www.lu.lv/studijas/fakultates/humanitaro-zinatnu-fakultate/bakalaura-limena-studijas/filologija/

LU MLBS (2021 March, 7) - Latvijas Universitāte. Moderno valodu un biznesa studijas. [Modern Language and Business studies.] Retrieved from: https://www.lu.lv/studijas/fakultates/humanitaro-zinatnu-fakultate/bakalaura-limenastudijas/moderno-valodu-un-biznesa-studijas/

LVA (2016). Valodas situācija Latvijā: 2010-2015: sociolingvistisks pētījums. [Language Situation in Latvia: 2010-2015: sociolinguistic research.] Rīga: Latviešu valodas aǵentūra, pp48.-67.

Maslo, E. (2003). Mācīšanās spēju pilnveide: monogrāfija. [Learning ability perfection: monograph.] Rīga: Raka, 2003, pp 192.

Prakselv (2021 March, 7). Starpkultūru sakari Latvija-Spānija https://www.prakse.lv/study/17445/latvijas-kulturasakademija/starpkulturu-sakari-latvija-spanija_ (07.03.2021)

Rozenberga, M.(2014). Spāṇu valoda: problēmas, kas saistītas ar tās apguvi pirmajā mācību posmā. [Spanish language: problems related to its acquisition in the first learning stage.] Valodu apguve: problēmas un perspektīva, X: zinātnisko rakstu krājums. Liepāja: LiePA, pp 255-265

Skola 2030. Valsts izglītības satura centrs. Kompetenču pieeja mācību saturā. [National Center for Education. Competence approach in learning content.] Retrieved from https://www.skola2030.lv/lv/skolotajiem/macibu-jomas/valodas

Stradiņš, J. (2007 October,8). Profesors Arnolds Spekke - jaunu ceḷu lauzējs Latvijas vēstures pētniecībā. [Professor Arnold Spekke - breaking up new roads in Latvia's history research.] Zinātnes vēstnesis 16 (350). Retrieved from http://ww3.lza.lv/ZV/zv071600.htm 